\title{
非接触眼軸長測定装置で測定した1年間の眼軸長変化の検討
}

野原 雅彦 $^{11}$ ・高橋まゆみ ${ }^{1)}$ ・柳平 朋子 $\left.{ }^{2}\right) \cdot$ 北澤 博子 ${ }^{2)}$

1) 丸子中央総合病院 眼科

2) 信州大学医学部 眼科

\section{Changes in Axial Length over One Year as Measured Using a Non-Contact Laser Interference Biometry}

\author{
Masahiko Nohara ${ }^{1)}$, Mayumi Takahashi ${ }^{1)}$, Tomoko Yanagidaira ${ }^{2)}$, \\ Hiroko Kitazawa ${ }^{2)}$ \\ 1) Department of Ophthalmology, Maruko Central General Hospital \\ 2) Department of Ophthalmology, Shinshu University School of Medicine
}

要 約

1 年間の眼軸長变化を非接触眼軸長測定装置で測定し、検討を行った。

外来を視力低下・屈折異常で受診した 3 歳から 18 歳の 235 人を対象とした。本人・保護者の同意の 上、非接触眼軸長測定装置（IOLマスターTM）で眼軸長を3-5回測定し、その平均值を使用した。ま た同時に、自然瞳孔下でオートレフ（RK-5 $\left.5^{\mathrm{TM}}\right)$ により屈折值を測定した。原則的に 1 年以上期間を 空けて 2 回目の測定を行い、変化值は測定間隔の日数で補正し、 1 年 365 日間での変化值に統一し た。

IOLマスターで測定した 1 年間での眼軸長の変化は、 $-0.11 \mathrm{~mm}$ か $0.94 \mathrm{~mm}$ であり、平均 $0.27 \mathrm{~mm}$ 、標 準偏差0.18mmであった。小学校低学年から小学校高学年で、眼軸長の伸展が大きい傾向にあった。小 学校低学年から高学年において、眼軸長が長い方が眼軸長の伸展が大きい傾向にあった。小学校低 学年から高学年において、屈折值が近視よりの方が眼軸長の伸展が大きかった。屈折值の変化がな くても眼軸長は伸展していたが、近視群は屈折值の変化が眼軸長変化に相関（ $\mathrm{R}^{2}=0.50 ）$ があった。

別冊請求先（テ386-0404）長野県上田市上丸子 $335-5$

丸子中央総合病院眼科 野原雅彦

Tel. 0268-42-1111 Fax. 0268-42-5437

Key words : non-contact laser interference biometry, change of axial length 非接触眼軸長測定装置、眼軸長变化 


\begin{abstract}
The present study was undertaken to compare changes in axial length as measured using a noncontact laser interference biometry with changes of ocular refraction measured simultaneously for one year.

The subjects of this study were 235 outpatients visiting our hospital, complaining of reduced visual acuity or refractive errors. Their ages ranged from 3 to 18 years. After obtaining consent from individual patients or their guardians, axial length of each patient was measured 3-5 times, using a non-contact laser interference biometry, and the mean of the 3-5 measurements was calculated. The measurement was repeated one year or more later, as a rule. The magnitude of change in axial length was corrected for the number of days between the two sessions of measurement and expressed as a change over one year (365 days). Refraction was measured simultaneously without use of accommodation paralysis. The magnitude of change in axial length during one year, as measured with a non-contact laser interference biometry, ranged from -0.11 to $0.94 \mathrm{~mm}$ (mean $0.27 \mathrm{~mm}$, standard deviation $0.18 \mathrm{~mm}$ ). The increase in axial length tended to be greater among children between the years of elementary school. The increase of axial length was greater in patients with a larger baseline axial length between the years of elementary school. In addition, the increase of axial length was greater in patients with more intense myopia as rated by the refraction between the years of elementary school. Patients without a change in refraction also showed an increase of axial length, but patients of myopia showing a change in refraction $t$ underwent a greater change of axial length.
\end{abstract}

\section{I．緒言}

近年、眼軸長の測定に際して、非接触眼軸長 測定装置が開発され、これまで眼軸長の測定が 困難だった年小児においても、非接触のため容 易に眼軸長が測定できるため、小览の眼屈折要 素の測定に応用されてきている1-4)。また、レ 一ザー干渉法を用いていることで、正確に眼軸 長が測定できるようになり5）6)、眼屈折要素の 内、屈折変化に大きく影響している眼軸長変化 が的確に捉えられることができるようになると 考えられた。今回、 1 年間の眼軸長变化を非接 触眼軸長測定装置で測定し、その結果を検討し た。また同時にオートレフで屈折值を自然睲孔 下で測定し、眼軸長と屈折值との比較検討を行 った。

\section{II. 対象及び方法}

対象は、外来を視力低下・屈折異常で受診し た 235 人（男 101 人女 134 人）で、年齢分布は図 1 の通りである。本人・保護者の同意の上、非 接触眼軸長測定装置（カールッアイス社製IOL
マスターTM) で眼軸長を3-5回測定し、その平均 值を使用した。また同時に、オートレフ（キャ ノン社製RK-5 $5^{\mathrm{TM}}$ ) で屈折值を自然瞳孔下で 5 回 以上測定し、さらに等価球面度数を計算した。 調節麻瘏剂は使用しなかったため、低年齢層や 遠視の症例では調節の関与が考えられるため、 今回の測定值は調節の介入が入っている可能性 のある屈折値と考えた。

初回測定の後、原則的に1年以上期間を空け 2 回目の測定を行なった。全例測定期間が同間隔 の 1 年365日間ではないため、変化值を同条件で 比較する必要があり、変化量を日数で補正し、 1 年365日間での変化值に統一した。変化量を $\mathrm{A}$ 、測定間隔を $\mathrm{B}$ 日とすると、 $\mathrm{A} \times \mathrm{B} / 365$ と いうように 1 年 365 日間の変化量を計算した。

角膜屈折力については、諸事情で今回は検討 することができなかったため、今後の課題とな った。

\section{III. 結 果}

IOLマスターで測定した 1 年間での眼軸長変 化は、 $-0.11 \mathrm{~mm}$ から $0.94 \mathrm{~mm}$ であり、平均 $0.27 \mathrm{~mm}$ 、 


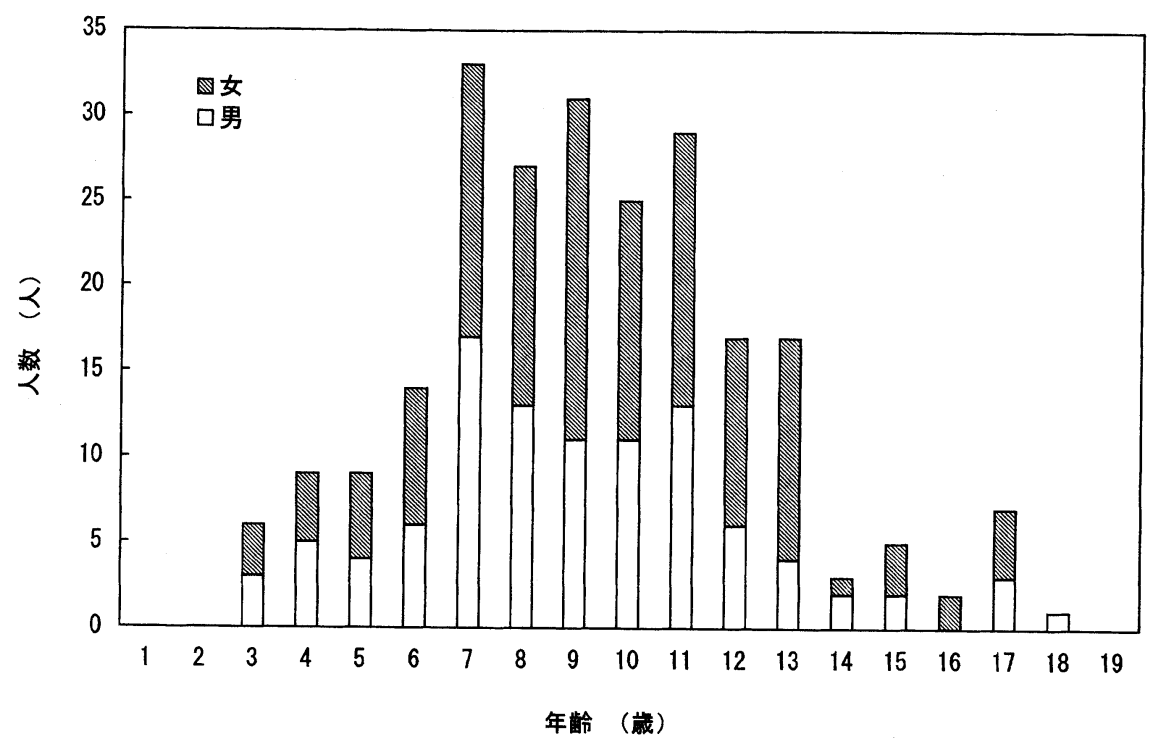

図 1 各年齢の対象者人数と男女別数

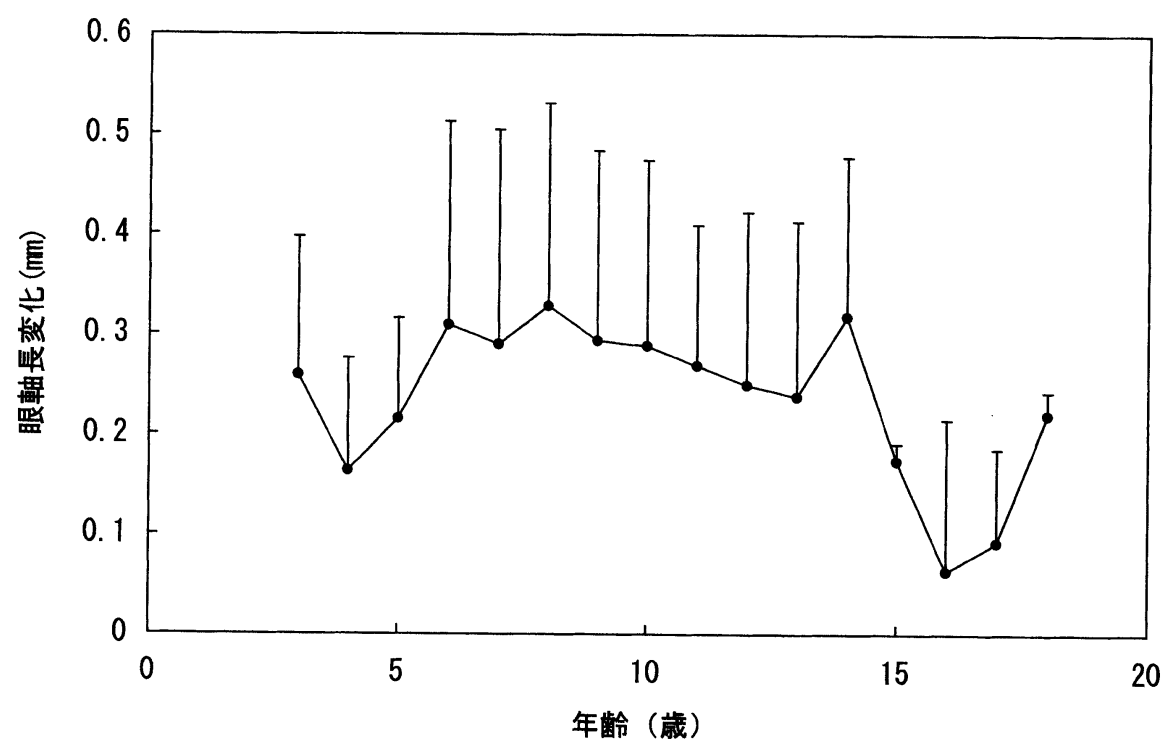

図 2 各年齢と眼軸長変化の平均と標準偏差

標準偏差0.18mmであった。

自然瞳孔下における、オートレフで測定した 屈折值は、等価球面度数で-14.25Dから+13.5D

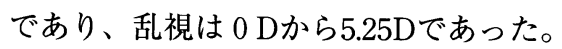

図 2 は、各年齢における眼軸長変化の平均と 標準偏差で、小学生低学年から高学年の年齢層 で眼軸長変化が大きい傾向にあった。各年代に よって眼軸長変化に差がある傾向だったため、
以後の眼軸長変化の解析は、小学校入学前 $(3$ ～ 5 歳)、小学校低学年 $(6 \sim 8$ 歳 $)$ と高学年 ( $9 \sim 11$ 歳)、中学生 $(12 \sim 14$ 歳)、高校生以降 （15歳以降）と年代別グループに分けて行った。

図 3 は、眼軸長と眼軸長変化との関係を各年 歯層に分けて検討したもので、全体では眼軸長 が長い方が、眼軸長の伸展が大きい傾向にあっ た。また、小学校低学年と高学年では眼軸長と 


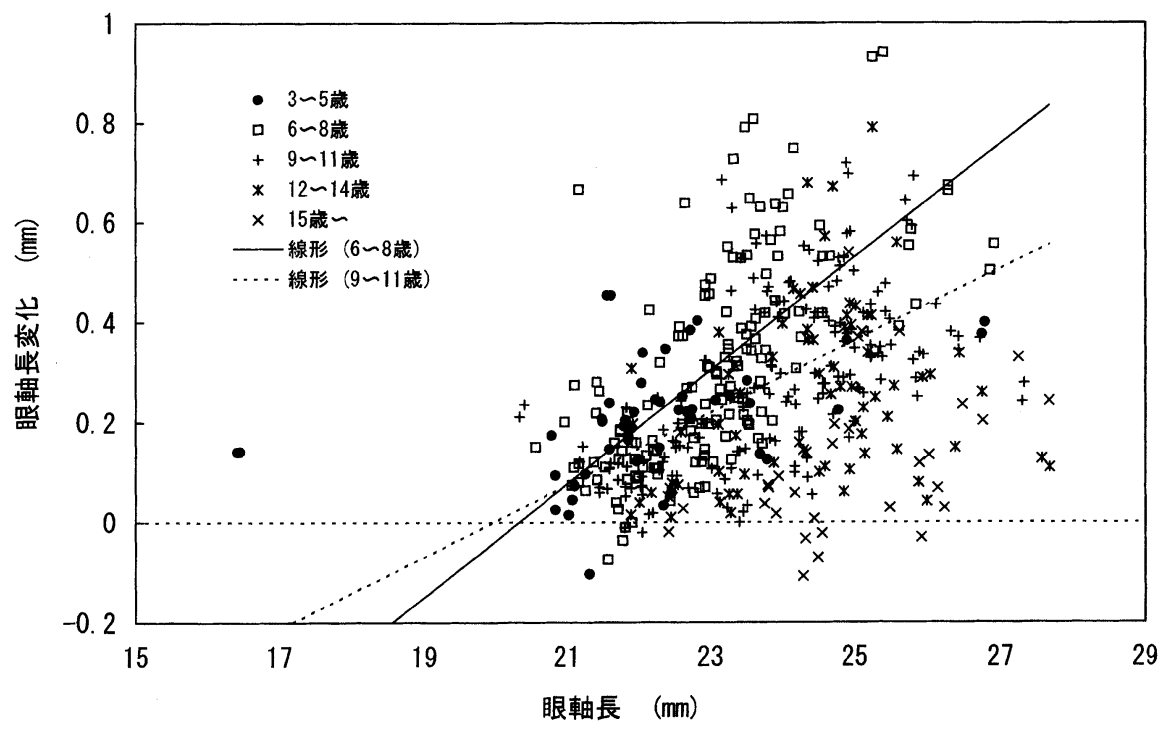

図 3 各年代別の眼軸長と眼軸長変化との関係

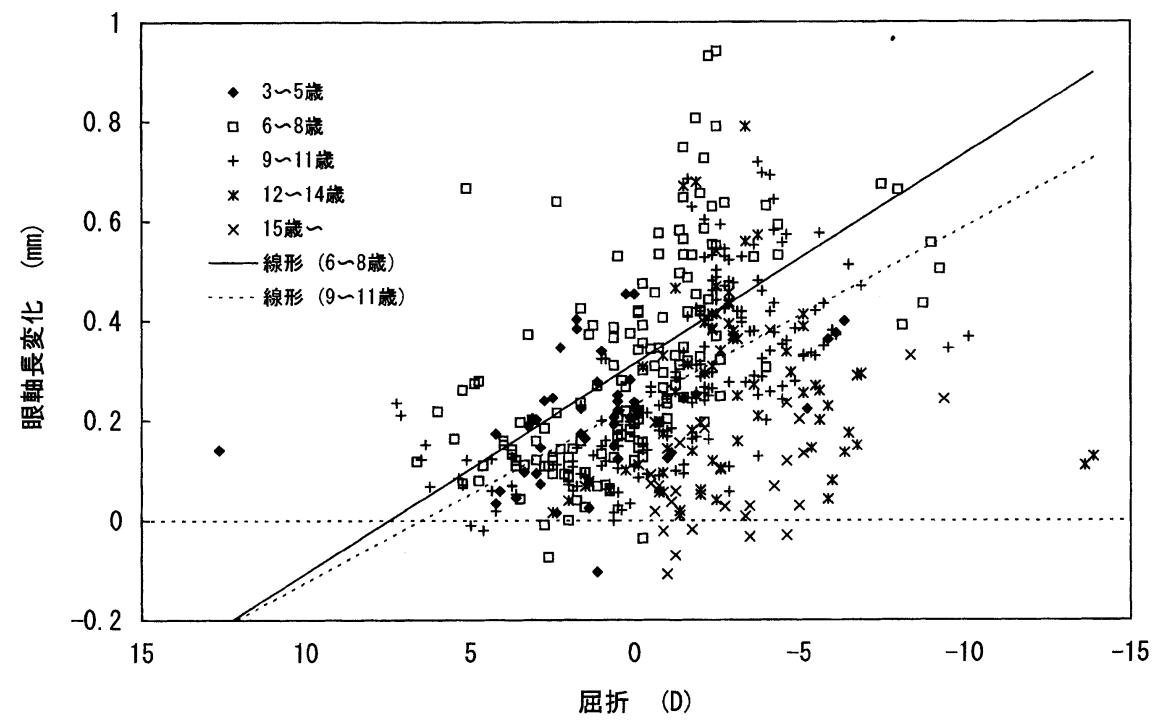

図 4 各年代別の屈折值と眼軸長変化との関係

眼軸長変化には中程度の相関があり（小学校低 学年 $\mathrm{R}^{2}=0.43$ 、高学年 $\mathrm{R}^{2}=0.34 ）$ 小学生低学年の 方が眼軸長の変化が大きい傾向にあった。

図 4 は、屈折值と眼軸長変化との関係を各年 齢層に分けて検討したもので、遠視眼でも眼軸 長は伸展していたが、近視眼の方が、眼軸長変 化が大きい傾向にあった。また、小学校低学年 と高学年では眼軸長と眼軸長変化には中程度の
相関があり（小学校低学年 $\mathrm{R}^{2}=0.35$ 、高学年 $\mathrm{R}^{2}=$ 0.41）小学生低学年の方が眼軸長の変化が大き い傾向にあった。

図 5 は、屈折値変化と眼軸長変化との関係を、 近視群 ( -1 D以下)、正視群、遠視群 (+ 1 D 以上）に分けてみたもので、遠視群、正視群で は、眼軸長がわずか進展していて、屈折值変化 があまりない例が多く、近視群では屈折度変化 


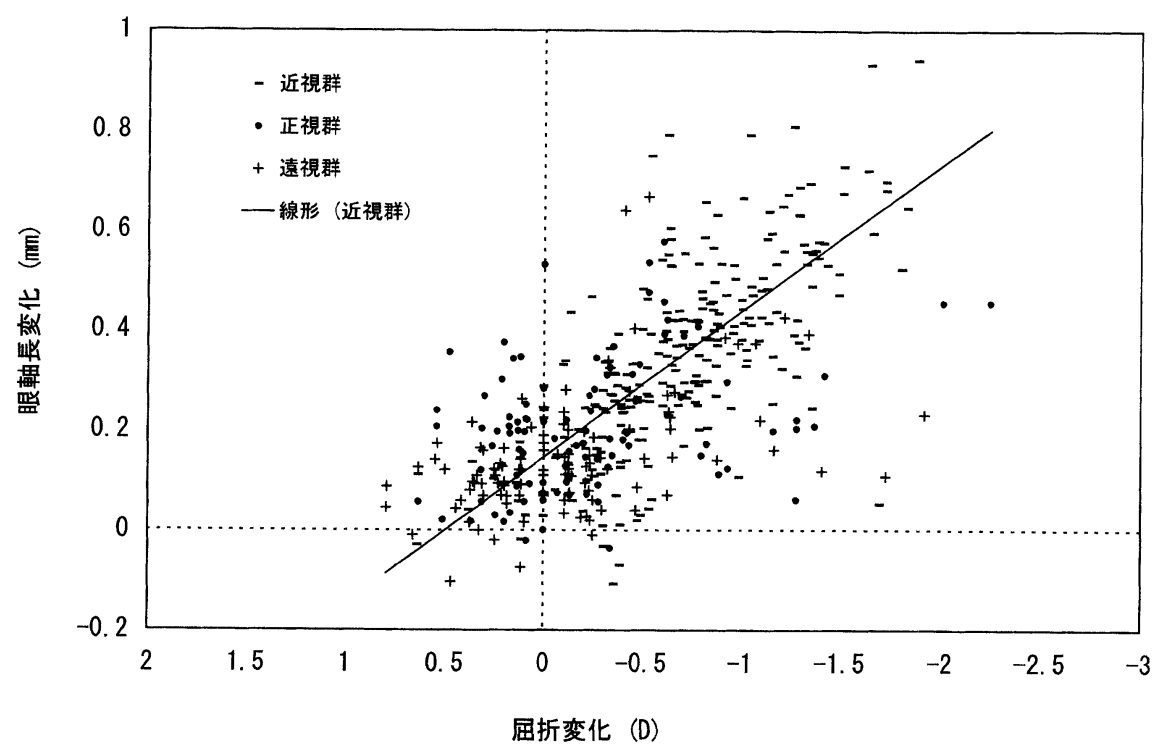

図 5 各屈折状態における屈折值変化と眼軸長変化との関係

と眼軸長変化の間に強い相関がみられ（ $\mathrm{R}^{2}=$ $0.50) 、$ 回帰直線の傾きは-0.2915であった。

ただ、今回は自然瞳孔下での測定であり、調 節麻痺剤は使用しなかったため、屈折值につい ては低年齢層ほど調節の関与が大きく入ってい る可能性があり、屈折值の分類や眼軸長との相 関についてはその点も考慮する必要があると考 えられた。

\section{IV. 考按}

今回、IOLマスターを使用しての眼軸長測定 は全例に可能であり、検查時間も 1 分程度の短 時間で終了し、外来診療を妨げるものではなか った。据え置き型オートレフで測定可能な固視 良好な小児であれば、簡便で精度の高い眼軸長 測定が可能であり、また、白内障手術時の眼軸 長測定時の様に、水晶体混濁が強くて測定不能 になる症例もなく、今後、小児の眼軸長測定の 主流になっていくものと思われた。

今回、小学校低学年と高学年の眼軸長変化が 大きい傾向にあり、中学生はそれに比べやや眼 軸長の変化が少ない傾向だったが、年代別に眼 軸長変化を検討した報告 ${ }^{7)}$ では、中学生に比べ 小学校低学年と高学年では眼軸長の進展が大き
かったとしており、われわれと同様の結果であ った。

眼屈折要素のうち、眼軸長の変化と近視の進 行を検討したものとして、 3 年間の眼軸長変化 と近視の進行とを比較検討し、 $\mathrm{R}^{2}=0.88$ の強い 相関があり、 3 年間の近視の進行度数 (D) は、 眼軸長変化 (mm) にー2.0を乗じた值になるとの 報告 ${ }^{8)}$ がある。今回我々も近視群で屈折変化と 眼軸長変化との関係を検討した結果では、やは り屈折が近視により変化した症例ほど、眼軸長 の変化が大きかったが、相関係数が $\mathrm{R}^{2}=0.50$ と やや低く、回帰直線より計算すると、屈折変化 （D）は、眼軸長変化（mm）に-3.43Dを乗じた 值となり、報告より眼軸長変化に比べ屈折変化 が大きくなる結果となった。

今回は調節麻痺剤を使用せず屈折検査を行っ たため、調節の要素が大きく関与している症例 も存在すると考えられる。近視学童を対象とし て調節麻痺剤点眼前後のオートレフで得られた 屈折值を比較した報告 ${ }^{9)}$ では、平均0.11D、最大 $0.8 \mathrm{D}$ の近視度数の軽減があるとされている。今 後は調節麻痺剂を使用することで、より的確に 屈折值を捉えることができ、IOLマスターによ る精度の高い眼軸長測定と合わせて、両者の相 関がより明白になっていくと考えられた。 
今回、IOLマスターで測定した 1 年間の眼軸 長の変化がマイナスになる例が散見され、最大 で-0.11mm眼軸長が短縮したように測定された症 例もみられた。IOLマスターについての測定值 の標準偏差が $0.02 \mathrm{~mm}$ との報告 ${ }^{5)}$ や、測定の $95 \%$ 信頼区間が $0.04 \mathrm{~mm}$ との報告 ${ }^{6)}$ がある。また、IOL マスターでは、測定値のばらつきが $0.1 \mathrm{~mm}$ 以内で 測定されると平均值が計算されるように設計さ れている。さらにIOLマスターは涙液層表面よ り眼軸長を測定しており、瞬目による涙液層の 厚さの変動や、眼軸長の調節による変動 ${ }^{10)}{ }^{11}$ 、 眼軸長の日内変動 ${ }^{12}$ などによる影響も考えられ た。

今回、近視群では眼軸長の変化とともに屈折 值はより近視に変化していたが、遠視、正視で は眼軸長が変化していても屈折値の変化があま りみられない症例が多かった。やはり小児に対 しIOLマスターで眼軸長を測定、オートレフケ ラトで屈折、角膜屈折力を測定した報告 ${ }^{4)}$ では、 遠視、正視では、眼軸長が延長しても水晶体屈 折力が低下し代償されるため、屈折值が遠視や 正視に保たれているのではないかと推察してい た。今回、諸事情で角膜屈折力の検討が行えな かったが、今後、角膜屈折力を検討し、また各 測定值から計算される水晶体屈折力の変化につ いて検討を行なうことによって、小児の眼屈折 要素の変化と屈折值の関係についてさらに解明 されていくのではないかと思われた。

\section{参考文献}

1) Ojaimi E, Robaei D, Rochtchina E, et al: Impact of birth parameters on eye size in a population-based study of 6-year-old Australian children. Am J Ophthalmol 140: 535-537, 2005.

2) Ojaimi E, Rose KA, Morgan IG, et al: Distribution of ocular biometric parameters and refraction in a population-based study of Australian children. Invest Ophthalmol Vis
Sci 46: 2748-2754, 2005.

3 ) Ojaimi E, Morgan IG, Robaei D, et al: Effect of stature and other anthropometric parameters on eye size and refraction in a populationbased study of Australian children. Invest Ophthalmol Vis Sci 46: 4424-4429, 2005.

4 ）山下 力, 宮崎茂雄, 瀧田能子, 他 : レーザ 一千涉非接触型眼軸長測定装置による小児の 屈折要素の検討. 眼紀 56：19-23，2005.

5 ）嶺井利沙子, 清水公也, 魚里 博, 他 : レー ザー干涉による非接触型眼軸長測定の検討. あたらしい眼科 $19: 121-124,2002$.

$6 ）$ 長谷部聡，木村修平，大月 洋：非接触眼軸 長測定装置を用いた早期発症近視の進行速度 の評価 (抄). 眼臨 $100 ： 440-441 ， 2006$.

7 ）大久保裕史, 大久保寿一：調節痘攣の学童 150 名にみられた眼屈折要素の性差. 眼臨 88 ： 1545-1549, 1994.

8 ) Hyman L, Gwiazda J, Hussein M, et. al : Relationship of age, sex, and ethnicity with myopia progression and axial elongation in the correction of myopia evaluation trial. Arch Ophthaomol 123: 977-987, 2005.

9 ) Hasebe S, Nonaka F, Nakatsuka C, et al: Myopia control trial with progressive addition lenses in Japanese schoolchildren: baseline measures of refraction, accommodation, and heterophoria. Jpn J Ophthalmol: 49: 23-30, 2005.

10) Mallen EA, Kashyap P, Hampson KM: Transient axial length change during the accommodation response in young adults. Invest Ophthalmol Vis Sci 47: 1251-1254, 2006.

11）山口華奈子, 堀部 円, 魚里 博, 他：近見 作業に伴う眼軸長，前房深度の変化. 視能訓 練士協会誌 $34: 115-119 ， 2006$.

12）庄司信行, 筒井健太, 新田任里江, 他：正常 若年者における眼軸長日内変動と眼圧の関連. あたらしい眼科 20：991-994， 2003. 